Relations industrielles

Industrial Relations

\title{
Determinants of Wildcat Strikes in Canada Manufacturing Industries
}

\section{Ignace $\mathrm{Ng}$}

Volume 42, numéro 2, 1987

URI : https://id.erudit.org/iderudit/050314ar

DOI : https://doi.org/10.7202/050314ar

Aller au sommaire du numéro

Éditeur(s)

Département des relations industrielles de l'Université Laval

ISSN

0034-379X (imprimé)

1703-8138 (numérique)

Découvrir la revue

Citer cet article

Ng, I. (1987). Determinants of Wildcat Strikes in Canada Manufacturing Industries. Relations industrielles / Industrial Relations, 42(2), 386-397.

https://doi.org/10.7202/050314ar
Résumé de l'article

This paper attempts to identify and to test the effects of a number offactors on the occurrence of wildcat strikes in Canada.

the occurrence of wildcat strikes in Canada. 


\title{
Determinants of Wildcat Strikes in Canada Manufacturing Industries
}

\author{
Ignace $\mathbf{N g}$
}

This paper attempts to identify and to test the effects of a number of factors on the occurrence of wildcat strikes in Canada.

From 1970 to $1979,23.2$ percent of all strikes and lockouts in Canada were intracontractual work stoppages ${ }^{1}$. This evidence clearly indicates that wildcat strikes ${ }^{2}$ are an integral part of the Canadian industrial relations system. Yet, a review of Canadian empirical research on strike activity reveals that there is virtually no econometric study explaining the occurrence of wildcat strikes. While wildcat strikes were not the central focus of their paper, Jones and Walsh (1984) conducted the only Canadian empirical study in this area ${ }^{3}$. They found that the conventional bargaining model is better at explaining contract renewal strikes than mid-term and unorganized strikes. Of the 13 variables included in the estimating equation for wildcat strikes, only plant size, proportion of female workers and a dummy for 1974 were significant. The factors likely to influence the occurrence of wildcat strikes in Canada are therefore yet to be determined. For example, what is the relationship between wildcat strikes and increased economic activity? Are injury-prone industries more likely to experience wildcat strikes? What is the influence of wages on the incidence of wildcat strikes?

To provide an answer to some of the above questions, the objective of this paper is to develop a model explaining the incidence of wildcat strikes, and to test the proposed model using pooled cross section-time series data for the 20 2-digit SIC Canadian manufacturing industries, 1982 and 1983 combined. A distinctive aspect of the proposed model is its use of the recently published injury data. While this variable has been used in a number of U.S. studies, no Canadian study has used it to explain strikes, whether contract-renewal or wildcat.

* NG, I., Assistant Professor, Department of Industrial Relations and Organizational Behaviour, College of Commerce, University of Saskatchewan.

1 See ANDERSON and GUNDERSON, (1982), Table 2, page 226.

2 In this paper, wildcat strikes are defined as work stoppages arising during the term of the collective agreement.

3 In contrast, there are several studies on wildcat strikes in the U.S. For a nonexhaustive list, see BYRNE and KING (1986), FLAHERTY (1983), WARDELL, VAUGHT, and EDWARDS (1982), and BRETT and GOLDBERG (1979). 
The following section of the paper presents the theoretical model. The third section deals with methodological problems, followed by the section on empirical results. The last section provides some concluding remarks.

\section{THEORETICAL UNDERPINNINGS}

At the present time, it does not appear that there exists a well developed theory of wildcat strikes upon which empirical research can draw. Hence, to justify the inclusion of the explanatory variables in the proposed estimating equation, the present study makes use of a number of hypotheses found in the literature on wildcat strikes. Because of data limitations, not all existing hypotheses can, however, be tested.

In a recent study, Byrne and King (1986) identified some key determinants of U.S. wildcat strikes. Given the similarity between the Canadian and U.S. industrial relations systems, this study could serve as a convenient starting point for analyzing wildcat strikes in Canada. These authors hvoothesized that wildcat strikes may occur (i) as a form of protest against unsafe working conditions, (ii) as a result of poor union-management relationship, and (iii) as a consequence of increased economic activity. To add to this list, three additional reasons for the occurrence of wildcat strikes are considered in the present study. Wildcat strikes may reflect the militancy of the work force, or they may reflect the rank-and-file dissatisfaction over the agreement negotiated by their bargaining representatives. Wildcat strikes may also serve as a tactical device for an upcoming contract-renewal negotiation. These six hypotheses form the basis for the variables included in the regression equation.

It should be noted that the reasons listed are by no means exhaustive. For example, Rees (1962) argues that many wildcat strikes occur because of the workers' dissatisfaction with union policies. This hypothesis is, however, not considered in this paper, because given that the unit of observation in the sample is industry by year, it was not possible to devise suitable proxies to capture the dissatisfaction of the workers with union policies.

The relationship between safety conditions and wildcat strikes should be positive. In industries where working conditions tend to be unsafe, workers are more likely to go on strike during the terms of agreement to force management to provide a safer working environment ${ }^{4}$. To control for the effect of safety conditions, the level of injuries in an industry (INJRAT) is used. High injury level is an indication of unsafe working conditions, and a positive relationship between INJRAT and wildcat strikes is therefore expected.

A poor union-management relationship would suggest that disputes between the two parties are less likely to be resolved in a peaceful manner. For example, protests over certain disciplinary actions adopted by manage-

4 This does not mean that going out on strike is an effective way of fostering changes in working conditions. The point, however, is that one is more likely to observe the occurrence of wildcat strikes in industries characterized by unsafe working conditions. 
ment may be channelled through the grievance procedure or through job actions. Where the relationship between the two parties is poor, there will be a tendency for the protests to generate into overt actions. Thus, wildcat strikes should be more frequent in this type of relationship. To capture the quality of the union-management relationship, the number of grievances or quit rates would have been preferred measures. Extensive search for these variables was, however, fruitless. Shorey (1976) argues that large plants are generally impersonal, with rigid work rules. The workers' interests in large plants are also more heterogeneous, thus making it more difficult to develop policies which would satisfy everyone. It is also likely that large plants will be faced with more labor relations issues than smaller plants. For these reasons, a good union-management relationship may be more difficult to maintain in large plants. It therefore follows that the average size of plants (SIZE) in an industry may be used as an inverse measure of the quality of union-management relationship in that industry. Thus, a positive coefficient is expected for SIZE in the estimating equation ${ }^{5}$.

During periods of high economic activity, it may be argued that firms would be more strict and demanding. For example, firms may be less willing to give time off or they may be unusually strict with the time taken for coffee breaks. High economic activity may also imply that the workers are overworked, and that they may be less willing to comply with management's directions. Workers may also see such times as more efficacious and "safe» to deal with longstanding gripes. What all these mean is that during increased economic activity, incidents may be overblown, thus increasing the likelihood of wildcat strikes occurring.

To measure to level of economic activity in an industry, the index of capacity utilization rate (CAPA) is used. An increase in the capacity utilization rate would indicate a rise in demand, and a corresponding increase in economic activity. This should in turn increase the occurrence of wildcat strikes. A positive relationship between CAPA and wildcat strikes is therefore anticipated.

With regard to the relationship between wildcat strikes and the militancy of the work force, it should be clear that the more militant the workers, the higher the likelihood of wildcat strikes occurring. To control for the effects of the militancy of the work force, two variables are included in the estimating equation. They are the proportion of production workers (BLUE) and the proportion of female workers (FEMALE) in an industry. These two variables have been discussed extensively in the (contractrenewal) strike literature ${ }^{6}$, and the concensus is that production workers relative to white-collar workers are more strike-prone, and that females are generally less strike-prone. To the extent that this willingness to strike is a reflection of the militancy of the workers in question, it is therefore hypothesized that industries with a high proportion of production workers

5 The variable SIZE may also pick up other effects, notably the extent of intra-union conflict between the members and the union leaders. To the extent that intra-organizational conflict induces the occurrence of wildcat strikes, the expected relationship between SIZE and the frequency of wildcat strikes is therefore given additional support.

6 For example, see STERN (1976), and MAKI and STRAND (1984). 
and a low proportion of females are likely to experience more wildcat strikes. Thus, a positive sign is expected for BLUE and a negative sign for FEMALE.

When the workers are dissatisfied with the contract negotiated by their leadership, it is possible that to show their disapproval of the contract agreement, the workers may resort to a walkout. To capture this possibility, the wage level (WAGE) and the workers' share of the output produced (SHARE) are included in the estimating equation. High wages and a large share of the output produced should reduce the dissatisfaction of the workers, and hence the likelihood that they will stage a walkout. In other words, the relationship between the number of wildcat strikes in an industry and these two variables should be negative. An alternative justification for including SHARE in the proposed model is that it represents the cost of a walkout to the workers relative to that of the employer. Assuming that a strike (whether wildcat or contract renewal) involves loss in output, a high value of SHARE would indicate that the workers stand to lose more than the firm in the event of a wildcat strike. Accordingly, the workers may be less inclined to stage a walkout.

Prior to, or during, contract negotiations, the union leadership may (informally) encourage the workers to stage a walkout. This may be used as a warning to management, should the negotiations fail. Walkouts may be condoned to inform management of existing problems associated with the current contract. Walkouts prior to negotiations may also serve as a notice of the upcoming bargaining agenda. All these possibilities therefore suggest industries with more contracts for renewal are also more likely to experience the occurrence of wildcat strikes. To measure this effect, the number of contracts (CONT) expired in an industry in a given year is added to the model $^{7}$. A positive relationship between this variable and the number of wildcat strikes is anticipated.

Finally, two additional explanatory variables are entered in the estimating equation. First, there is union density (UNION) in an industry, and this is to account for the possibility that industries with more union workers would experience more wildcat strikes, other things equal. The second variable is a dummy variable (DUMMY), which takes on the value of 1 for 1983. A significant estimated coefficient on this variable would suggest the level of wildcat strikes in Canadian manufacturing industries differs in the two years considered.

To summarize, the proposed estimating equation is:

$$
\begin{aligned}
\text { WILDCAT }_{\mathrm{ij}}= & a_{0}+\mathrm{a}_{1} \text { INJRAT }_{\mathrm{ij}}+\mathrm{a}_{2} \text { SIZE }_{\mathrm{ij}}+\mathrm{a}_{3} \text { CAPA }_{\mathrm{ij}}+ \\
& \mathrm{a}_{4} \text { BLUE }_{\mathrm{ij}}+\mathrm{a}_{5} \text { FEMALE }_{\mathrm{ij}}+\mathrm{a}_{6} \text { WAGE }_{\mathrm{ij}}+\mathrm{A}_{7} \\
& \text { SHARE }_{\mathrm{ij}}+\mathrm{a}_{8} \text { CONT }_{\mathrm{ij}}+\mathrm{a}_{9} \text { UNION }_{\mathrm{ij}}+\mathrm{a}_{10} \\
& \text { DUMMY }_{\mathrm{j}}+\mathrm{e}_{\mathrm{ij}},
\end{aligned}
$$

7 Because of data limitation, this variable consists of only those contracts covering 500 workers or more. This variable may also not be perfect in capturing the effect of interest, since contract negotiations often start prior to the expiry of the collective agreement. 
where $i$ denotes industry and $j$ denotes year. WILDCAT is the number of wildcat strikes, INJRAT is number of injuries per 100 employees, SIZE is the number of workers per establishment, CAPA is the index of capacity utilization rate, BLUE is the number of production workers divided by total employment, FEMALE is the proportion of female workers in employment, WAGE is the wage level, SHARE is the ratio of total wages to value added, CONT is the number of expired contracts, UNION is union density, DUMMY is a dummy variable with $1983=1$, and $\mathrm{e}$ is the error term ${ }^{8}$. Positive signs are expected for $a_{1}, a_{2}, a_{3}, a_{4}, a_{8}$, and $a_{9}$, and negative signs are anticipated for $a_{5}, a_{6}$, and $a_{7}$. No sign expectation is hypothesized for $a_{10}$.

\section{METHODOLOGICAL ISSUES}

The foremost methodological problem encountered in this study is the measurement of the data series, especially the number of wildcat strikes by industry. The source for this variable is from Strikes and Lockouts in Canada, which lists work stoppages by industry and the issues involved with such stoppages. There is, however, no breakdown in terms of contract status. To generate the dependent variable, the issues do provide a good indication of whether a particular work stoppage is wildcat (for example, reinstatement of a fired worker versus wage issue). Unfortunately, in a number of cases, the reason for the work stoppage is not reported. For these cases, any stoppage of 48 hours or less is (arbitrarily) considered wildcat. The arbitrary nature in which wildcat strikes are measured suggests that the reliability of the estimates may be affected, due to possible error in measurement. A more detailed examination of the sample reveals that the effect of the measurement error should be minimal. Of the 603 strikes occurring in 1982 and 1983, 14 did not report the cause of the stoppage. When the 48 hours criterion is used, 3 of the 14 strikes would be considered wildcat. When a 10 days criteria is used, 5 of the 14 strikes would be reported as wildcat. While this indicates that the measurement of the dependent variables varies with the criterion used, it is also clear that the effect is quite small.

The second problem is that the rationale for the inclusion of the independent variables is not based upon a well developed theoretical model. Rather, they are justified using a number of hypotheses discussed in the literature on wildcat strikes. Such approach, as noted by Maki and Strand (1984), does not enhance our understanding of the competiting theories of strikes, nor does it allow the testing of any particular theory9. While the shortcomings of this approach cannot be denied, it is, however, still useful in that it helps identify the key determinants of wildcat strikes in Canada, especially if one considers the limited number of studies on this type of strikes.

8 See the attached appendix for more details on the data and their sources.

9 Notable exceptions are REDER and NEUMANN (1980) and MAKI and STRAND (1984). Most empirical strike studies, however, use the approach adopted in this paper. For example, see BYRNE and KING (1986), JONES and WALSH (1984), FLAHERTY (1983), and SWIDINSKY and VANDERKAMP (1982). 
The third problem is that the present study has omitted a number of other factors, such as intra-union conflict, which may have an influence on wildcat strikes. These factors would have been considered were it not for data limitations. The proposed empirical model is therefore underspecified, and the results should be treated with caution because of possible biases in the estimates ${ }^{10}$.

Finally, I should mention that data for all variables, with the exception of INJRAT, have been collected for the period, 1974 to 1983, inclusive. I, however, chose to focus on the last two years, since the injury data across manufacturing industries are not available for the other years. Because of the limited time frame from which the data are drawn upon, the present paper is unable to provide any pattern of wildcat strikes over time.

\section{EMPIRICAL RESULTS}

The means and standard deviations of the variables are presented in Table 1, and the OLS results are shown in the first column of Table 2. Of the 9 explanatory variables with predicted signs, 8 are correct, with 4 being significant at 0.01 level. Judging from the corrected R-square, the proposed model explains about 29 percent of total variation. This figure is lower than the 0.43 value estimated by Byrne and King (1986) in their study of U.S. wildcat strikes, possibly due to the lower number of observations used in the present study.

For example, the corrected R-square was 0.4 in Jones and Walsh (1984) and 0.15 in Swidinski and Vanderkamp (1982).

Turning to the individual coefficients, the variable INJRAT is significant, but contrary to expectations, the sign is negative. That is, industries with high levels of injuries are less likely to experience wildcat strikes. In contrast, Byrne and King reached the opposite conclusion for the U.S. To reconcile these conflicting results, consider the occupational health and safety laws that exist in Canada and the U.S. The major piece of legislation that deals with health and safety issues in the U.S is the Occupational Safety and Health Act (OSHA) of $1970^{11}$. Among other things, the Act provides the employee the right to notify the Occupational Safety and Health Administration of any violation of standard, and to request an OSHA inspection. In Canada, the health and safety laws are decentralized. In a number of jurisdictions, notably British Columbia, New Brunswick, Northwest Territories, Ontario, Saskatchewan, Yukon, and to a certain extent, Québec, the relevant statute requires the establishment of joint health and safety committees in workplaces exceeding a certain number of workers ${ }^{12}$.

10 ROOMKIN (1976) noted that a well specified strike model should account for 'the interdependence of union's and management's bargaining positions'. This in effect calls for a 2-equation model. Since there is virtually no empirical strike study which utilizes such a model, Roomkin argued that most econometric models of strike activity are thus underspecified.

11 See ASHFORD (1979), page 12.

12 This number varies across jurisdictions. For more details, see NASH (1983), page 63. 
TABLE 1

Means and Standard Deviations of Variable

$\begin{array}{lrc}\text { Variable } & \text { Mean } & \text { Std. Deviation } \\ \text { WILDCAT } & 1.08 & 2.17 \\ \text { INJRAT } & 7.97 & 4.00 \\ \text { SIZE } & 90.49 & 82.91 \\ \text { GT200 } & 0.08 & 0.09 \\ \text { CAPA } & 70.08 & 15.40 \\ \text { BLUE } & 0.69 & 0.13 \\ \text { FEMALE } & 0.28 & 0.18 \\ \text { WAGE } & 10.26 & 2.44 \\ \text { SHARE } & 0.52 & 0.14 \\ \text { CONT } & 6.28 & 5.8 \\ \text { UNION } & 0.42 & 0.17 \\ \text { DUMMY } & 0.5 & 0.5\end{array}$

For our purpose, the point to note is that in the U.S., a high level of injuries at the workplace may induce the workers to call for an inspection by an OSHA official. To the extent that such action may lead to a rise in the level of tension at the workplace, one should therefore observe a positive association between injury levels and wildcat strikes. On the other hand, in Canada, a high level of injuries should increase the level of interaction between union and management, through the joint health and safety committees. With this increased contact between the parties, it is plausible to argue this may in turn induce the parties to adopt a problem-solving approach with other isssues, thus reducing the likehood of wildcat strikes ${ }^{13}$. It therefore appears that a possible reason why the level of injuries has a negative effect on wildcat strikes in Canada and a positive effect in the U.S., is the existence of health and safety committees to handle issues, such as injuries. If the interaction effect of these committees could have been controlled for, the estimated results in this paper would have probably shown a positive relationship between injuries and wildcat strikes.

With regard to the proxy for the quality of union-management relationship it is insignificant and has the wrong sign. Given that the mean value of SIZE is approximately 90 workers per plant, it may be possible that plants of this size are not «large» enough to experience the difficulties discussed by Shorey. Subsequently, I re-ran equation 1, replacing SIZE by

13 It is also possible to rationalize the negative sign on injuries, by arguing that the estimated coefficient is capturing the eventual impact of wildcat strikes in reducing injuries over time. This argument is, however, not pursued any further for 2 reasons. First, if the argument was correct, the study by Byrne and King would have also estimated a negative sign on the injury variable. Second, I did examine the effect of wildcat strikes on the future level of injuries. With a t-value of 0.09 on the strike variable, it does not appear that wildcat strikes were effective in reducing the level of injuries. 


\section{TABLE 2}

Regression Results

(dependent variable $=$ WILDCAT, $t$ values in parentheses)

\begin{tabular}{|c|c|c|c|c|}
\hline $\begin{array}{l}\text { Independent } \\
\text { Variable }\end{array}$ & $\begin{array}{l}\text { Predicted } \\
\quad \text { Sign }\end{array}$ & Eq. 1 & Eq. 2 & Eq. 3 \\
\hline INJRAT & + & $\begin{array}{l}-0.36 \\
(-2.79)\end{array}$ & $\begin{array}{c}-0.28 \\
(-2.15)\end{array}$ & \\
\hline SIZE & + & $\begin{array}{l}-0.01 \\
(-1.37)\end{array}$ & & $\begin{array}{l}-0.01 \\
(-1.60)\end{array}$ \\
\hline GT200 & + & & $\begin{array}{c}0.38 \\
(0.06)\end{array}$ & \\
\hline CAPA & + & $\begin{array}{c}0.02 \\
(1.00)\end{array}$ & $\begin{array}{c}0.01 \\
(0.64)\end{array}$ & $\begin{array}{c}0.03 \\
(1.94)\end{array}$ \\
\hline BLUE & + & $\begin{array}{c}6.36 \\
(1.88)\end{array}$ & $\begin{array}{c}6.73 \\
(1.88)\end{array}$ & $\begin{array}{c}-0.17 \\
(-0.08)\end{array}$ \\
\hline FEMALE & - & $\begin{array}{l}-8.40 \\
(-2.87)\end{array}$ & $\begin{array}{l}-8.04 \\
(-2.68)\end{array}$ & $\begin{array}{r}-6.88 \\
(-4.17)\end{array}$ \\
\hline WAGE & - & $\begin{array}{l}-0.07 \\
(-0.57)\end{array}$ & $\begin{array}{l}-0.16 \\
(-1.18)\end{array}$ & $\begin{array}{l}-0.23 \\
(-1.28)\end{array}$ \\
\hline SHARE & - & $\begin{array}{l}-3.47 \\
(-1.38)\end{array}$ & $\begin{array}{l}-2.55 \\
(-0.98)\end{array}$ & $\begin{array}{l}-0.54 \\
(-1.55)\end{array}$ \\
\hline CONT & + & $\begin{array}{c}0.05 \\
(0.92)\end{array}$ & $\begin{array}{c}0.06 \\
(1.02)\end{array}$ & $\begin{array}{c}0.11 \\
(2.76)\end{array}$ \\
\hline UNION & + & $\begin{array}{c}7.63 \\
(2.72)\end{array}$ & $\begin{array}{c}5.45 \\
(1.79)\end{array}$ & $\begin{array}{c}8.91 \\
(3.76)\end{array}$ \\
\hline DUMMY & & $\begin{array}{c}0.46 \\
(0.78)\end{array}$ & $\begin{array}{c}0.52 \\
(0.84)\end{array}$ & \\
\hline TIME & & & & $\begin{array}{c}-0.04 \\
(-0.26)\end{array}$ \\
\hline Corrected R-Square & & 0.29 & 0.25 & 0.33 \\
\hline $\mathrm{n}$ & & 40 & 40 & 200 \\
\hline
\end{tabular}

another variable (GT200), which includes only those plants with two hundred workers or more. The results are presented in equation 2 , and they are discussed below.

The index of capacity utilization rate has the anticipated sign with wildcat strikes, but is insignificant. This may be partially due to the fact that only two years are considered in the present sample. As we shall see later, when a longer time frame is considered, this variable does attain significance. The two variables measuring the militancy of the work force are both significant and have the hypothesized signs. In other words, industries with high proportion workers (BLUE) and low proportion of female workers (FEMALE) should experience more wildcat strikes than otherwise. 
The results suggest that wages do not have an influence on the likelihood of a walkout. That is, while low wage earners may be less satisfied and therefore more likely to stage a walkout, this willingness to engage in a wildcat strike may be dampened because low wage earners are also less able to afford such activity. The estimated result on SHARE suggests that the workers' share of value added has no effect on the occurrence of wildcat strikes. This may be due to the same reason as to why the level of wages has no effect on the occurrence of wildcat strikes. Industries with a large number of expired contracts (CONT) are not likely to experience more wildcat strikes, while industries with a high degree of unionization (UNION) are more likely to experience such activities. Finally, it does not appear that there is any significant difference in the pattern of wildcat strikes between 1982 and 1983.

Column 2 of Table 2 re-estimates equation 1, replacing the variable SIZE by GT200, defined as the proportion of establishments with two hundred workers or more. The results suggest that industries with a high proportion of large plants are no more prone to wildcat strikes than industries with a low proportion of large plants. It therefore appears that the size of plants is invariant to the frequency of wildcat strikes. More importantly, however, the estimated results indicate that the evidence presented in Column 1 are quite stable. There is no sign reversal and no change in the significance of the explanatory variables.

Column 3 of Table 2 presents the OLS results, using a larger sample. The data are pooled cross section-time series, but unlike Column 1, the estimating period is from 1974 to 1983 , inclusive. The variable INJRAT has been excluded because data were not available, and the variable DUMMY has been replaced by a time trend (TIME), which starts 1 for 1974 .

Comparing Columns 1 and 3, BLUE is no longer significant while SIZE, CAPA and CONT have now attained significance. FEMALE and UNION stay significant with the expected signs in both cases. Judging from the corrected R-square, it appears that the proposed model is better at explaining variations in wildcat strikes over a longer time period.

\section{CONCLUSION}

The purpose of this paper has been to examine the key determinants of the occurrence of wildcat strikes in Canada. The model estimated suggests that level of injuries has an inverse effect on wildcat strikes, presumably through the interaction effects of health and safety committees. This makes sense, especially if one considers that outside contract negotiations, the bargaining parties have few channels of communications to deal with issues arising during the terms of the contract. Joint committees and the grievance procedure are two such channels. Evidence by Byrne and King indicates that frequent use of the grievance procedure tends to reduce the occurrence of wildcat strikes. By analogy, one may argue that frequent use of joint committees may also have a similar effect on wildcat strikes. Given that high level of injuries increases the use of joint committees, and hence the communication flow between the parties, it therefore follows that under these 
circumstances, other incidents are less likely to degenerate into walkouts. On the other hand, in the U.S. where there is no provision for the establishment of joint committees to deal with health and safety issues, the workers who are concerned over their safety may have no option but to stage a walkout. This explains the positive relationship estimated between injuries and the number of wildcat strikes. Thus, the conflicting results between the study by Byrne and King and the present study over the effect of injuries on wildcat strikes may stem from the absence of health and safety committees in the U.S.

The estimated results also suggest that if the workforce is more militant, one is also likely to observe more wildcat strikes occurring in an industry. Finally, highly unionized industries are also more likely to experience the incidence of wildcat strikes. For future research, it may be fruitful to use micro data, so that firm-specific factors can be accounted for. It may also be useful to analyze the historical pattern of wildcat strikes to increase our understanding of how various labor legislation (for example, PC 1003) affect the occurrence of wildcat strikes.

\section{BIBLIOGRAPHY}

ANDERSON, J. and M. GUNDERSON, «Strikes and Dispute Resolution», in J. Anderson and M. Gunderson (eds.), Union-Management Relations in Canada, Don Mills, Ontario, Addison-Wesley, 1982, pp. 220-244.

ASHFORD, N.A., Crisis in the Workplace - Occupational Disease and Injury, Cambridge, Massachusetts, The MIT Press, 1979.

BRETT, J.M. and S.B. GOLDBERG. «Wildcat Strikes in Bituminous Coal Mining», Industrial and Labor Relations Review, 32, 1979, pp. 465-483.

BYRNE, D.M. and R.H. KING, "Wildcat Strikes in U.S. Manufacturing, 1960-1977», Journal of Labor Research, 4, 1986, pp. 387-401.

COUSINEAU, J.M. and R. LACROIX, «Activité économique, inflation et activité de grève», Relations Industrielles, 31, 1976, pp. 341-358.

FLAHERTY, S., «Contract Status and the Economic Determinants of Strike Activity", Industrial Relations, 22, 1983, pp. 20-33.

JONES, J.C.H. and W.A. WALSH, «Inter-Industry Strike Frequencies: Some Pooled Cross-Sectional Evidence from Canadian Secondary Manufacturing», Journal of Labor Research, 5, 1984, pp. 419-425.

KENNEDY, P., A Guide to Econometrics, London, England, Martin Robertson and Co. Ltd., 1979.

MAKI, D. and K. STRAND, «The Determinants of Strike Activity - An Interindustry Analysis», Relations Industrielles, 39, 1984, pp. 77-91. 
NASH, M.I., Canadian Occupational Health and Safety Law Handbook, Don Mills, Ontario, CCH Canadian Limited, 1983.

REDER, M. and G. NEUMANN, «Conflict and Contract: The Case of Strikes», Journal of Political Economy, 80, 1980, pp. 867-886.

REES, A., The Economics of Trade Unions, Chicago, University of Chicago Press, 1962.

ROOMKIN, M., «Union Structure, Internal Control and Strike Activity», Industrial and Labor Relations Review, 29, 1976, pp. 198-217.

SHALEV, M., "Trade Unionism and Economic Analysis: The Case of Industrial Conflict», Journal of Labor Research, 1, 1980, pp. 133-173.

SHOREY, J., "An Investigation of Industrial Strike Activity in Britain", Economica, 43, 1976, pp. 349-365.

STERN, R., «Intermetropolitan Pattern of Strike Frequency», Industrial and Labor Relations Review, 25, 1976, pp. 218-235.

SWIDINSKY, R., and J. VARDERKAMP, «A Micro-Econometric Analysis of Strike Activity in Canada», Journal of Labor Research, 3, 1982, pp. 455-471.

WARDELL, M.L., C. VAUGHT and J.N. EDWARDS, «Strikes: A Political Economy Approach», Social Science Quarterly, 63, 1982, pp. 409-427.

\section{APPENDIX VARIABLE DEFINITIONS AND DATA SOURCES}

WILDCAT: Number of wildcat strikes. The source for this variable is from Labour Canada, Strikes and Lockouts in Canada. Any work stoppage arising from employee suspension, disciplinary act, firing, demotion, safety, use of non-union workers, layoffs, support of colleagues, respecting picket lines, sympathy, application of contract terms, jurisdictional dispute, job classification, grievances, contracting out, and travel allowance would be considered wildcat. Where the cause of the stoppage is not reported, any stoppage of less than 48 hours would also be considered wildcat.

INJRAT: Number of injuries per 100 employees. Data for injuries by industry are from Labour Canada. Workers Compensation Injury Statistics, 1982-84, uncatalogued. Data for employment are from Statistics Canada, 31-203.

SIZE: $\quad$ Number of employees divided by the number of establishments. The establishment data are from Statistics Canada, 31-203. 
GT200: Number of establishments with 200 workers or more divided by the total number of establishments in the industry. The data for this variable are from Statistics Canada, 31-203.

SHINV: $\quad$ Shipments of finished goods divided by inventories of finished goods. Data for shipments and inventories are both from Statistics Canada, Canadian Statistical Review.

BLUE: Number of production workers divided by total employment. Data for both production workers and employment are from Statistics Canada, 31-203.

FEMALE: Number of female workers divided by total employment. The source for this variable is from Statistics Canada, 31-203.

WAGE: $\quad$ Average hourly earnings. Statistics Canada, 72-002.

SHARE: Total wages divided by value added. Data for both variables are found in Statistics Canada, 31-203.

CONT: Number of expired contracts covering 500 workers or more. Canada, Department of Labour, Calendar of Expiring Collective Agreements.

UNION: Number of union workers divided by total employment. Data for union membership are from Statistics Canada, 71-202.

\section{RÉGIMES DE SANTÉ ET SÉCURITÉ ET RELATIONS DU TRAVAIL}

Preface, Gilles FERLAND - Introduction, Rodrigue BLOUIN, René BOULARD, Jean-Paul DESCHENES, Michel PERUSSE - Régimes de santé et sécurité et relations du travail, Michel PERUSSE - Priorités en santé et sécurité du travail: secteur public et secteur privé, Marcel SIMARD - Commentaires, Jean-Guy LEDUC, Maurice LEMELIN, Alain VINET - Concertation et participation: mythe ou réalité?, Florian OUELLET - Commentaires, Anne-Chantal DUMAS, Monique SIMARD - Table ronde - La santé et la sécurité dans l'entreprise, Robert BOUCHARD, Pierre-R. CLEMENT, Etienne GIASSON, Michel GUILLEMETTE - L'impact de la Loi sur les conventions collectives, René BOULARD - Droit de refus et retrait préventif: succès ou échec?, Marie de KONINCK, Roy HEENAN, - La prévention: une utopie?, Fernand TURCOTTE Commentaires, Claude DROUIN, Denise PLAMONDON - Santé et sécurité du travail: une affaire de professionnels?, Jacques BRUNET - Les coats et bénéfices du régime, Gilles BEAUSOLEIL Table ronde - Deceptions et espoirs, Ghislain DUFOUR, Frank FAVA, Jean-Paul HETU, Louis LABERGE, Gérald LAROSE, Robert SAUVE.

ISBN 2-7637-7045-2

1 volume - 285 pages - 1984 - Prix: $\$ 17.00$

Les Presses de l'Université Laval

Cité universitaire

C.P. 2447. Québec, P.Q., Canada G1K 7R4 